\title{
Pigmented Pseudoalteromonas Sp. Isolated from Marine Sponge with Anti-Microbial Activities against Selected Human Pathogens
}

\author{
Awanis Rosmadi and Tengku Haziyamin Tengku Abdul Hamid
}

\section{ABSTRACT}

\begin{abstract}
Marine sponges have been the potential source of bioactive compounds with potent antimicrobial properties. Sponge associated microbes significantly provide the route of biosynthesis of some of these compounds. In this work, a total of $\mathbf{1 0 0}$ bacterial colonies were screened from a marine sponge from Class Demospongiae, which has been collected from Merambong Island, the state of Johor, Malaysia. In disk diffusion assay, only 2 out of 100 isolates; namely $\mathrm{C40}$ and $\mathrm{C52}$, were able to demonstrate active inhibitions against selected human pathogens (Pseudomonas aeruginosa, Escherichia coli, Bacillus subtilis, except for Staphylococcus aureus). Isolates $\mathrm{C} 40$ and $\mathrm{C} 52$ were characterized to be Gram negative short rods, non-spore formers and catalase positive. Unlike the majority of other isolates from sponge which were Gram positive rods, Isolate $\mathrm{C40}$ and C52 are Gram negative rods which grew in yellow pigmented colonies. Genotypic characterization using 16S ribosomal RNA sequencing were carried out on each isolate (accession number for $\mathrm{C40}$ and $\mathrm{C52}$ is MT645493 and MT645494, respectively). The 16S ribosomal RNA sequences revealed that these strains belonged to genus Pseudoalteromonas sp. with $\mathbf{9 7 - 9 8 \%}$ similarities. Inhibitions studies showed that this sponge associated microorganisms potentially produce anti-microbial compounds useful for biotechnologies.
\end{abstract}

Keywords: Anti-microbial activities, Gammaproteobacteria, Pseudoalteromonas, Sponge associated microorganisms.
Published Online: September 22, 2020

ISSN: $2684-5199$

DOI: $10.24018 /$ ejbio.2020.1.5.87

\section{Awanis Rosmadi}

Department of Biotechnology, Kulliyyah of Science, International Islamic University Malaysia, Malaysia.

(e-mail: awanis.rosmadi@yahoo.com)

Tengku Haziyamin Tengku Abdul Hamid *

Department of Biotechnology, Kulliyyah of Science, International Islamic University Malaysia, Malaysia. (e-mail: haziyamin ${ }^{\circledR i i u m . e d u . m y) ~}$

*Corresponding Author

\section{INTRODUCTION}

Microorganisms have been the prime sources to derive natural products which were developed as commercial products destined for human healthcare and agricultural uses. With the advent of new 'omics' technologies based on structural bioinformatics, metabolomics or gene expression, the new field of microbial genome mining propels further the applications in natural product discovery and development [1]. Despite of these advancements, the emergence of antibiotic resistant microorganisms has made the quest to find novel biologically active compound a never ending research endeavor [2]. Even though the terrestrial plants and microorganisms have been the significant contributors to natural product discovery, these sources are still limited as they are not easy to propagate or readily available.

As an alternative to terrestrial sources, researchers have been resorting to marine as an interesting source for bioactive compounds. Marine sources are believed to offer substantially different microbial communities from that of terrestrial environment. Marine invertebrates have been the largest contributors to marine bioactive compound production and these compounds have shown high incidence of cytotoxicity [3]. There are more than 15,000 marine natural compounds being isolated and studied, about one third of these are derived from Sponges (Phylum Porifera). Evolutionarily, sponges are ancient metazoans (multicellular) that can normally be found abundant in tropical oceans, but they can also dwell the temperate oceans as well as the freshwater. Sponges harbour large and diverse population of bacteria in their matrix tissues and this account to approximately $40 \%$ of their biomass. Sponges are considered as holobiont, a recent concept of describing complex organism relying on the tight association between the host and microbiota that inhabit it [4]. The symbiotic interactions between sponges and microbiome will facilitate host for nutrient acquisition, structural stabilization of the sponge skeleton, metabolism and processing of waste, and production of secondary metabolite [5].

It was discovered that bioactive compounds from sponges are actually synthesized in pathways involving microorganisms, or completely produced by the microorganisms themselves. The diversity of sponges, and microbiota they harbour have inspired many works targeting various compounds with biotechnological potentials. Malaysia is a mega biodiversity country and it was 
surrounded largely by oceans. Several studies have been carried out to isolate diverse microorganisms from various types of sponges collected from Malaysian waters, or nearby regions. In Malaysia, various types of sponges were recently sampled; and the sponge associated microbes were studied for useful products or enzymes. These include rare Actinomycetes (Tioman island) [6]; polysaccharides producing Theonella sp. (Bidong island) [7]; pigmented bacterium (Tinggi Island) [8]; several cultivable bacterium (Bidong Island) [9]; and Streptomyces (Andaman sea) [10]; haloalkanoic acid degrading Bacillus aryabhattai [11]; and moderately halophilic lipase producing bacterium (Pahang coast) [12]. The potential of sponge associated microbes in bioprospecting of bioactive compound have been described [13], [14]. Recently, a metagenomic approach was also used to profile microbial diversity in sponge collected from Bidong and Redang islands in Terengganu [15]. This work is to highlight on the isolation and characterization of yellow pigmented bacteria which were isolated from a sponge sample (Class Demospongiae) collected from Merambong Island, an island located at Tebrau straits, Johor. These isolates were subjected to bacterial inhibition studies against selected human pathogens. This sponge associated microbes produce useful antimicrobial agents which have biotechnological potential.

\section{MATERIALS AND MethodS}

\section{A. Sample collection and bacterial strains}

The marine sponge sample was collected from Pulau Merambong (Merambong Island) which is situated in Johor, Malaysia $\left(1.3153^{\circ} \mathrm{N}, 103.6102^{\circ} \mathrm{E}\right.$, see Fig 1). The sponge was collected by a team of SCUBA divers from Institute of Oceanography (INOCEM), International Islamic University Malaysia. Sponge sample was immediately transported and stored at $-20{ }^{\circ} \mathrm{C}$ before extraction. Sponge was thawed, cut into small pieces using sterile blade. About $100 \mathrm{~g}$ of sponge tissues was suspended in $100 \mathrm{~mL}$ sterilized sea water and homogenized. The extract was diluted up to $10^{-1}-10^{-3}$ and about $100 \mu \mathrm{L}$ from each extract dilution was spread on Marine agar (MA) 2216 (55.1 $\mathrm{gL}^{-1}$, Difco), followed by incubation at $25{ }^{\circ} \mathrm{C}$ for 48 hours. Single colonies that formed were selected and sub-cultured again into the MA.

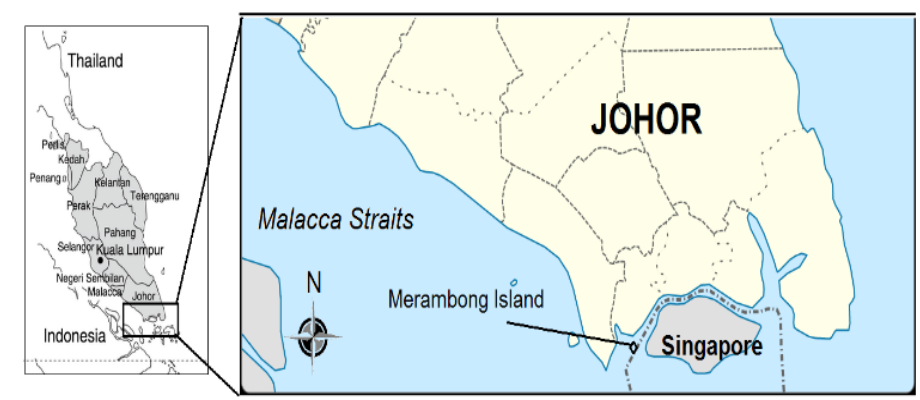

Fig. 1. Location of Merambong island, the State of Johor in Peninsular Malaysia. were carried out using standard protocol as carried out elsewhere [16].

\section{Disk diffusion methods}

Four indicator bacterium; Pseudomonas aeruginosa (ATCC 14028), Escherichia coli (ATCC 35218), Bacillus subtilis (ATCC 14579), Staphylococcus aureus (ATCC 25923) were previously purchased from American Culture Collection Centre (ATCC) and maintained at Kulliyah of Science collection. The strains were cultivated at $35^{\circ} \mathrm{C}$ for 24 hours in $10 \mathrm{~mL}$ Nutrient broth $(\mathrm{NB})$ until reaching $1-2 \times 10^{8}$ $\mathrm{CFUml}^{-1}$. About $100 \mu \mathrm{L}$ of the broth were spread evenly onto Nutrient agar (NA) plates, incubated until bacterial lawn formation which were used in subsequent disk diffusion tests.

Antagonistic tests were carried out using disk diffusion methods [17]. The bacterial strains were inoculated into 10 $\mathrm{mL}$ Marine broth (Difco) until turbidity reached at 0.5 McFarland standard. About $10 \mu \mathrm{L}$ of the cell suspension was dispensed onto sterile paper disc. The disc was left to dry and the procedure was repeated 5 times until a total of $50 \mu \mathrm{L}$ broth samples were dispensed. The impregnated discs were placed firmly onto the surface of NA agar plate with lawn of indicator bacterium and this was incubated at $25{ }^{\circ} \mathrm{C}$ for 48 hours. The Marine broth was used as negative control, and antibiotic (Gentamycin, $25.0 \mu \mathrm{gmL}^{-1}$ ), as positive control. The diameter of the zone of inhibition that formed surrounding the disc was measured (in $\mathrm{mm}$ ).

\section{Genotypic characterization}

The genomic DNA was extracted from selected bacterial strains using GF-1 Bacterial DNA extraction kit (Vivantis) according to manufacturer protocols. The DNA samples were then used as template for PCR amplification of 16S rRNA gene using a pair of universal primer (forward: 5' - AGA GTT TGA TCC TGG CTC AG - 3' and reverse 5' - CCG TCA ATT CCT TTG AGT TT- 3') [18]. Each PCR reaction mixture in $50 \mu \mathrm{L}$ volumes was added with $2 \mu \mathrm{L}(50-100 \mathrm{ng})$ DNA sample, 1.5 of each primer and $25 \mu 1$ of $2 x$ Master mix (Promega). Amplifications cycle (Mastercycler, Germany) was set as follows: Initial denaturation $\left(94{ }^{\circ} \mathrm{C}, 2 \mathrm{~min}\right)$ followed by 30 cycles of denaturation $\left(94^{\circ} \mathrm{C}, 50 \mathrm{~s}\right)$; annealing $\left(44{ }^{\circ} \mathrm{C}, 50 \mathrm{~s}\right)$; and extension $\left(72{ }^{\circ} \mathrm{C}, 1.5 \mathrm{~min}\right)$; followed by a final extension $\left(72{ }^{\circ} \mathrm{C}, 3.5 \mathrm{~min}\right.$ and hold at $\left.4{ }^{\circ} \mathrm{C}\right)$. The PCR products were purified using PCR purification kit (GeneJet, Fermentas). The DNA bands was analyzed using $1 \%$ agarose gel electrophoresis, stained with Ethidium bromide $(0.5 \mathrm{~g} / \mathrm{mL})$ and visualized using gel documenter (Alpha Imager 2200). The genomic DNA samples were sent to sequencing agency (Apical Scientific, Sdn. Bhd) and generated sequences were cleaned and analyzed using BLASTN search at http://www.ncbi.nlm.nih.gov. The phylogram was constructed based on Neighbour-joining methods (NGphylogey.fr) using an online tool available at https://ngphylogeny.fr/. At NCBI Genbank, each deposited sequence was assigned with an accession number MT645493 and MT645494 (for C40 and C52 respectively).

\section{B. Colony and morphology characterizations}

Colonies that formed were analyzed for their appearances, optical property, pigmentation, texture, form, elevation and margin. Gram staining, spore staining, motility, catalase tests 


\section{RESUlTS AND DISCUSSION}

In this work, about 100 colonies were successfully subcultured from the sponge sample and studied. Gram staining results showed that the majority of the isolates (94\%) are gram positive bacterium (Table 1). None of the Gram positive sample showed inhibition on the indicator bacterium used. However, 2 out of 6 Gram negative isolates were able to show inhibitions and these two isolates; C40 and C52, were selected for further studies. Generally, Isolate C40 and C52 appeared as Gram negative rods which are catalase positive and non-spore forming microbes. The colonies morphology and characteristic exhibited by these strains were shown on Table 2. Biochemical and morphological data were compared with genotypic data of which the rRNA sequencing result (see discussion later) had identified these isolates belonged to Pseudoalteromonas sp. The colony morphologies or characteristics such as yellow to red colour, either translucent or opaque optical property, circular shape, convex elevation with entire margin are common features displayed by Pseudoaltermononas species [19], [20], [21]. Nevertheless, some variations were still being reported indicating that different Pesudoalteromonas species may not show similar colony appearances.

TABLE 1: MORPHOLOGICAL DISTRIBUTION OF MICROBIAL ISOLATES FROM SPONGE AND INHIBITORY PROPERTIES

\begin{tabular}{cccccc}
\hline \multirow{2}{*}{$\begin{array}{c}\text { Gram Staining } \\
\text { Properties }\end{array}$} & \multicolumn{3}{c}{ Positive (Purple) } & \multicolumn{2}{c}{ Negative (Pink) } \\
\cline { 2 - 6 } Shapes & \multicolumn{2}{c}{94} & \multicolumn{2}{c}{6} \\
\hline & Rods & Cocci & Rods & Cocci \\
\cline { 2 - 6 } & 10 & 84 & 3 & 3 \\
\hline Inhibition & - & - & 2 & - \\
\hline
\end{tabular}

TABLE 2: COLONIES CHARACTERISTIC, STAINING, MORPHOLOGIES AND BIOCHEMICAL TESTS

\begin{tabular}{ccc} 
& \multicolumn{2}{c}{ Isolates } \\
\cline { 2 - 3 } Observations & C40 & C52 \\
Colonies & Yellow & Yellow \\
Pigmentation & Translucent & Opaque \\
Optical properties & Smooth & Smooth \\
Texture & Circular & Circular \\
Form & Convex & Pulvinate \\
Elevation & Entire & Entire \\
Margin & & \\
Morphologies & Negative & Negative \\
Gram staining & Rods & Rods \\
Shape & + & + \\
Catalase & - & - \\
Spore & &
\end{tabular}

Based on results shown in Table 3, studies using disk diffusion method showed that Isolates C40 and C52 showed varying inhibitions against indicator strains. Isolate $\mathrm{C} 40$ was able to inhibit Gram negative Escherichia coli and Gram positive Bacillus subtilis, but not against gram negative Pseudomonas aeruginosa or Gram positive Staphylococcus aureus (Fig. 2). In contrast, Isolate C52 showed antagonisms against Gram positive Bacillus subtilis and Gram negative Pseudomonas aeruginosa.
TABLE 3: INHIBITORY ACTIVITIES OF ISOLATE C40 AND C52 AGAINST SELECTED INDICATOR STRAINS

\begin{tabular}{|c|c|c|c|c|}
\hline \multirow[b]{2}{*}{$\begin{array}{l}\text { Indicator } \\
\text { bacterium }\end{array}$} & \multicolumn{4}{|c|}{ Inhibition zone $( \pm 0.1 \mathrm{~mm})$} \\
\hline & $\begin{array}{c}\text { Positive } \\
\text { control } \\
\text { (Gentamycin) }\end{array}$ & $\begin{array}{c}\text { Negative } \\
\text { control } \\
\text { (Marine broth) }\end{array}$ & $\begin{array}{c}\text { Isolate } \\
\text { C40 }\end{array}$ & $\begin{array}{c}\text { Isolate } \\
\text { C52 }\end{array}$ \\
\hline Escherichia coli & 24.0 & N/A & 13.0 & N/A \\
\hline Bacillus subtilis & 28.0 & N/A & 15.0 & 10.0 \\
\hline $\begin{array}{c}\text { Staphylococcus } \\
\text { aureus }\end{array}$ & 24.0 & N/A & N/A & N/A \\
\hline $\begin{array}{c}\text { Pseudomonas } \\
\text { aeruginosa }\end{array}$ & 22.0 & N/A & N/A & 15.0 \\
\hline
\end{tabular}

N/A - no activity
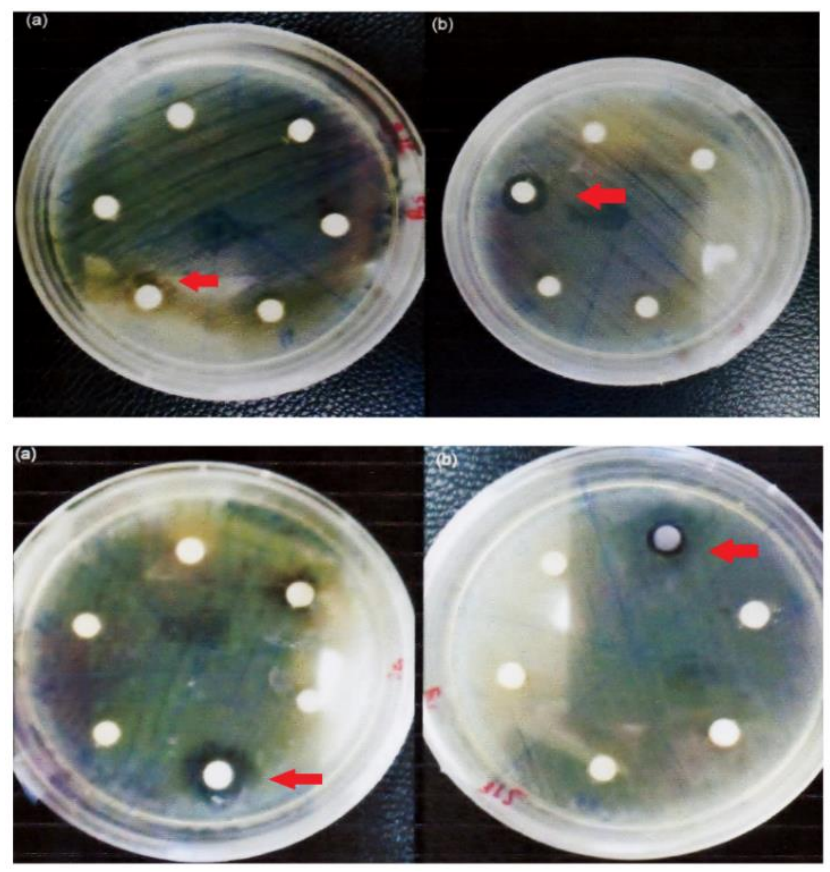

Fig. 2. Examples of inhibitory activities of isolates C40 and C52 against indicator strains using disk diffusion methods. Upper panel: Inhibition activities (arrow) of sample C40 against a) B. subtilis; and b) E. coli. Lower panel: Inhibitory activities (arrows) of C52 against a) $P$. aeruginosa; and d) B. subtilis. All other disks were corresponded to other isolates.

Ability to exhibit inhibitions against both Gram positive and negative strains implied that these isolates showed broad spectrum inhibition and different types of metabolites could have been produced by these organisms. Pseudoalteromonas species are known to produce diverse antimicrobial metabolites which can potentially be harnessed for future antimicrobial agents [22]. These metabolites include alkaloids or peptides, polyketides, terpenoids and bacteriocin like substance (BLIS). In view of the rise and concern in antibiotic resistance among human pathogen, these metabolites should be considered and studied for potential antimicrobial agents.

The 16S ribosomal RNA were successfully amplified from both DNA sample form C40 and C52 samples, and the Fig. 3 shows the amplified product of size $\sim 1.5 \mathrm{~kb}$ visualized using $1 \%$ agrose gel electrophoresis. Based on $16 \mathrm{~S}$ ribosomal RNA sequencing, both C40 and C52 strains have high similarity (at least 98\%) with several Pseudoalteromonas species (e.g. P. tetraodonis and $P$. issachenkonji). An example of a hit list generated from similarity searches using BLASTN was shown in Table 4 for isolate C40 (list for C52 are similar, not shown). Since their similarities are just below $98.7 \%$, these isolates can only be identified up genus level, and they are referred to as Pseudoalteromonas sp. Fig. 4 shows a 
phylogenetic tree was constructed containing the 16S rRNA sequences of Isolate $\mathrm{C} 40$ and $\mathrm{C} 52$ with other related Pseudoalteromonas species from the hit list. Isolates C40 and C52 present in a branch that radiates together with strains $P$. issachenkonii and P. tetraodonis. There is another sister branch that clusters $P$. spiralis, $P$. elyakovii, $P$. haloplanktis, $P$. nigrifacien, $P$. antarctica and $P$. espejiama. All of these branches together with $P$. mariniglutinosa are clustered within a bigger clade which is split from many other Pseudoalteromonas members. In this tree, a strain Shewanella japonica which is the furthest distant member, forms an outgroup.

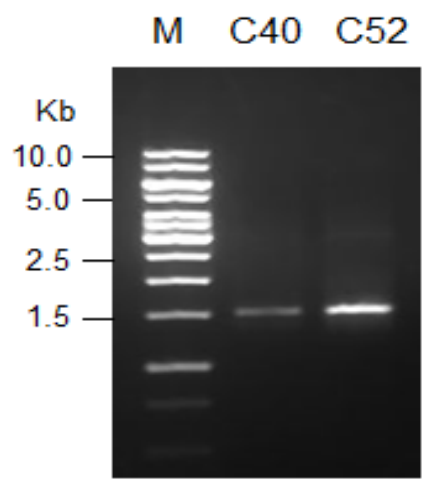

Fig 3. Agarose gel (1\%) electrophoresis showing the amplified bands of sizes $1.5 \mathrm{~kb}$ corresponding to the $16 \mathrm{~S}$ ribosomal RNA gene for both isolates; C40 and C52. Lane M is standard 1 kb ladder marker and other lanes are labelled with isolates C40 and C52.

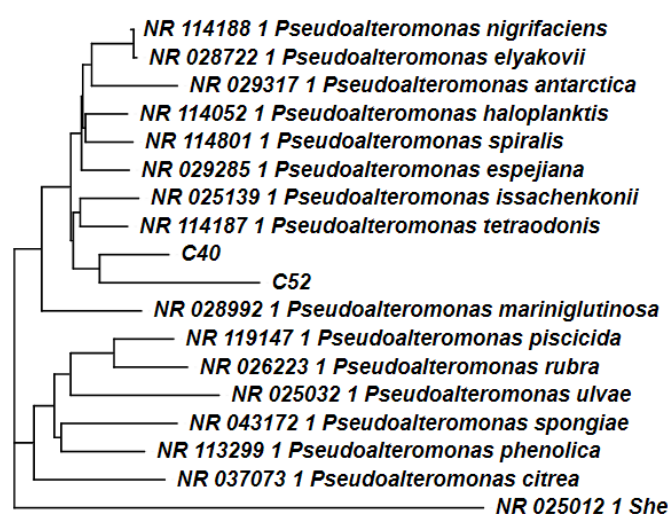

Time scale: $0.01 \longmapsto$

Fig 4. A Phylogram generated using Neigbour-joining methods to indicate the relative position of two Pseudalteromonas sp. strains C50 and C52 isolated from marine sponges at Merambong Island, with other Pseudoalteromonas strains.
The 16S ribosomal RNA were successfully amplified from both DNA sample form C40 and C52 samples, and the Figure 3 shows the amplified product of size $\sim 1.5 \mathrm{~kb}$ visualized using $1 \%$ agrose gel electrophoresis. Based on $16 \mathrm{~S}$ ribosomal RNA sequencing, both C40 and C52 strains have high similarity (at least 98\%) with several Pseudoalteromonas species (e.g. P. tetraodonis and P. issachenkonii). An example of a hit list generated from similarity searches using BLASTN was shown in Table 4 for isolate C40 (list for C52 are similar, not shown). Since their similarities are just below $98.7 \%$, these isolates can only be identified up genus level, and they are referred to as Pseudoalteromonas sp. Fig. 4 shows a phylogenetic tree was constructed containing the $16 \mathrm{~S}$ rRNA sequences of Isolate C40 and C52 with other related Pseudoalteromonas species from the hit list. Isolates C40 and C52 present in a branch that radiates together with strains $P$. issachenkonii and P. tetraodonis. There is another sister branch that clusters $P$. spiralis, $P$. elyakovii, $P$. haloplanktis, $P$. nigrifacien, $P$. antarctica and $P$. espejiana. All of these branches together with $P$. mariniglutinosa are clustered within a bigger clade which is split from many other Pseudoalteromonas members. In this tree, a strain Shewanella japonica which is the furthest distant member, forms an outgroup.

The genus Pseudoalteromonas belongs to the class Gammaproteobacteria which is ubiquitously heterotrophic bacterium common in the marine ecosystem [23]. Pseudoalteromonas was formerly grouped under genus Alteromonas, but later taxonomic revision following the availability of phylogenetic data has re-grouped them into a new genus Agricola [24]. Due to their characteristic biofilm formation and anti-fouling properties, Pseudoalteromonas has received many attentions in ecology [25]. Ability to produce wide varieties of bioactive compounds has also gathered interest in them for natural product source [23]. Members from this genus can then be divided nicely into two groups; i.e., non-pigmented and pigmented species. The pigmented species are more diverse and normally produce bioactive compounds, and the non-pigmented species is however less so. Since, both isolates C40 and C52 have the properties of Gram negative pigment producing Pseudoalteromonas species, the future prospect of these two strains should further be explored for biotechnology product.

TABLE 4: Similarity Hit LiST GENERATED FROM NCBI BLASTN SEARCH FOR C52 16s RRNA GENE SEQUENCE

\begin{tabular}{|c|c|c|c|c|}
\hline Strains & $\begin{array}{l}\text { Accession } \\
\text { Number }\end{array}$ & $\begin{array}{c}\text { Percentage } \\
\text { identity }(\%)\end{array}$ & E-value & Score \\
\hline Pseudoalteromonas issachenkonii strain KMM 3549 16S & NR_025139.1 & 98.4 & 0 & 2248 \\
\hline Pseudoalteromonas tetraodonis GFC strain IAM 14160 & NR_041787.1 & 98.4 & 0 & 2246 \\
\hline Pseudoalteromonas spiralis strain Te-2-2 & NR_114801.1 & 98.4 & 0 & 2241 \\
\hline Pseudoalteromonas elyakovii strain KMM 162 & NR_028722.1 & 98.2 & 0 & 2230 \\
\hline Pseudoalteromonas espejiana strain 261 & NR_029285.1 & 98.2 & 0 & 2200 \\
\hline Pseudoalteromonas mariniglutinosa strain KMM 3635 & NR_028992.1 & 97.4 & 0 & 2128 \\
\hline Psychrosphaera aestuarii strain PSC101 & NR_133832.1 & 90.7 & 0 & 1690 \\
\hline Shewanella loihica strain PV-4 & NR_074815.1 & 91.2 & 0 & 1674 \\
\hline
\end{tabular}




\section{CONCLUSION}

In this work, two strains of marine bacteria from Pseudoalteromonas sp. have successfully been isolated from a sponge tissues of Class Demospongiae, which was previously collected near Merambong Island, Johor, Malaysia. These yellow pigmented strains exhibited all the common characteristics of Pseudoalteromonas species which have also been reported from other marine sponges or other marine organisms and ecosystems. These strains demonstrated antagonisms against several human pathogens, both from Gram positive and negative bacterium. These antimicrobial properties of these strains should be explored further for future or novel bioactive compounds.

\section{ACKNOWLEDGMENT}

The authors wish to thank to International Islamic University Malaysia and Ministry of High Education Malaysia for financial assistance involved in this work (Grant no RIGS17-089-0664 IIUM KPT).

\section{REFERENCES}

[1] Katz, L. and Baltz, R.H., "Natural product discovery: past, present, and future," Journal of Industrial Microbiology \& Biotechnology, vol. 43 , no. 2-3: pp. 155-176, 2016.

[2] Brinkmann, C.M., Marker, A., and Kurtböke, D.İ., "An Overview on Marine Sponge-Symbiotic Bacteria as Unexhausted Sources for Natural Product Discovery," Diversity, vol. 9, no. 4: pp. 40, 2017.

[3] Khalifa, S.A.M., Elias, N., Farag, M.A., Chen, L., Saeed, A., Hegazy, M.F., Moustafa, M.S., Abd El-Wahed, A., Al-Mousawi, S.M., Musharraf, S.G., Chang, F.R., Iwasaki, A., Suenaga, K., Alajlani, M., Göransson, U., and El-Seedi, H.R., "Marine Natural Products: A Source of Novel Anticancer Drugs," Marine Drugs, vol. 17, no. 9, 2019.

[4] Pita, L., Rix, L., Slaby, B.M., Franke, A., and Hentschel, U., "The sponge holobiont in a changing ocean: from microbes to ecosystems," Microbiome, vol. 6, no. 1: pp. 46, 2018.

[5] Hentschel, U., Hopke, J., Horn, M., Friedrich, A.B., Wagner, M., Hacker, J., and S, M.B., "Molecular evidence for a uniform microbial community in sponges from different oceans," Applied and Environmental Microbiology, vol. 68, no. 9: pp. 4431-4440, 2002.

[6] Vikineswary, S., Christabel, L.J., Thong, K.L., Tan, G.Y.A., and Affendi, Y.A., Sponges of Tioman and their actinomycetes inhabitants., in Natural history of the Pulau Tioman Group of Islands, P.e. al., Editor 2008, IOES monograph series . University of Malaya, Kuala Lumpur. p. 35-41.

[7] Mohd Din, L.H., Ahmad, S., and Ismail, N., (2nd August 2020)"Polysaccharides-producing bacteria isolated from marine sponge, Theonella sp. and their bioactivities," AACL Bioflux, vol. [Online]. 11(5): $\quad$ pp., $2018 . \quad$ Available: http://www.bioflux.com.ro/docs/2018.1548-1556.pdf

[8] Jafarzade, M., N.A., Y., S., M., G., U., and Ahmad, A., "Isolation and characterization of pigmented bacteria showing antimicrobial activity from Malaysian marine environment," Malaysian Journal of Microbiology, vol. 9, no. 2: pp. 152-160, 2013.

[9] Amelia, T.S.M., Amirul, A.A., Saidin, J., and Bhubalan, K., "Identification of Cultivable Bacteria from Tropical Marine Sponges and Their Biotechnological Potentials," Tropical Life Sciences Research, vol. 29, no. 2: pp. 187-199, 2018.

[10] Baskaran, R., Thenmozhi, S., Kumar, K.V., Mohan, P.M., and Vijayakumar, R., "Streptomycetes associated with marine sponges collected from Andaman Sea; and Its antibacterial activity," Malaysian Journal of Microbiology, vol. 13, no. 3: pp. 253-260, 2017.

[11] Sufian, N., N, H., Naim, M., Hamid, T.A.T.H., Huyop, F., and Hamid, A.A.A., "Isolation and identification of 3-chloropropionic acid degrading bacterium from marine sponge," Jurnal Teknologi, vol. 77, no., 2015.

[12] Hamid, T.H.A., hamid, A.A.A., and Padzil, N.H., "Isolation of moderately halophilic lipase producing bacteria from sponges in Pahang coastal water, Malaysia," Jurnal Teknologi, vol. 77, no., 2015.

[13] Indraningrat, A.A.G., Smidt, H., and Sipkema, D., "Bioprospecting Sponge-Associated Microbes for Antimicrobial Compounds," Marine
Drugs, vol. 14, no. 5: pp. 87, 2016.

[14] Selvin, J., Ninawe, A., Kiran, S., and Lipton, A., "Sponge-microbial interactions: Ecological implications and bioprospecting avenues," Critical Reviews in Microbiology, vol. 36, no.: pp. 82-90, 2010.

[15] Amelia, T.S.M., Lau, N.-S., Amirul, A.A., and Bhubalan, K., (29th August 2020)"Metagenomic data on bacterial diversity profiling of high-microbial-abundance tropical marine sponges Aaptos aaptos and Xestospongia muta from waters off Terengganu, South China Sea," Data in Brief, vol. [Online]. 31(105971, 2020. Available: https://doi.org/10.1016/j.dib.2020.105971

[16] Abiola, C. and Oyetayo, V.O., "Isolation and Biochemical Characterization of Microorganisms Associated with the Fermentation of Kersting's groundnut (Macrotyloma geocarpum)," Journal of Microbiology, vol. 11, no. 2-3: pp. 47-55, 2016.

[17] Zain, N.A.M., Salikan, N.A., and K, Y.K., "Isolation of Antibiotic Resistant Bacteria from Rivers in Terengganu, Malaysia," International Journal of Life Sciences and Biotechnology, vol. 3, no. 3: pp. 241-257, 2020.

[18] Edwards, U., Rogall, T., Blocker, H., Emde, M., and Bottger, E.C., "Isolation and direct complete nucleotide determination of entire genes.," Nucleic Acid Research vol. 17, no.: pp. 7843-7853, 1989.

[19] Khalifa, A. and Aldayel, M., "Isolation and characterisation of the agarolytic bacterium Pseudoalteromonas ruthenica," Open Life Sciences, vol. 14, no.: pp. 588-594, 2019.

[20] Lau, S.C.K., Tsoi, M.M.Y., Li, X., Dobretsov, S., Plakhotnikova, Y., Wong, P.K., and Qian, P.Y., "Pseudoalteromonas spongiae sp. nov., a novel member of the gamma-Proteobacteria isolated from the sponge Mycale adhaerens in Hong Kong waters," International Journal of Systematic and Evolutionary Microbiology, vol. 55, no. Pt 4: pp. 1593$1596,2005$.

[21] Ivanova, E.P., Shevchenko, L.S., Sawabe, T., Lysenko, A.M., Svetashev, V.I., Gorshkova, N.M., Satomi, M., Christen, R., and Mikhailov, V.V., "Pseudoalteromonas maricaloris sp. nov., isolated from an Australian sponge, and reclassification of [Pseudoalteromonas aurantia] NCIMB 2033 as Pseudoalteromonas flavipulchra sp. nov," International Journal of Systematic and Evolutionary Microbiology, vol. 52, no. Pt 1: pp. 263-271, 2002.

[22] Seal, B.S., Drider, D., Oakley, B.B., Brüssow, H., Bikard, D., Rich, J.O., Miller, S., Devillard, E., Kwan, J., Bertin, G., Reeves, S., Swift, S.M., Raicek, M., and Gay, C.G., "Microbial-derived products as potential new antimicrobials," Veterinary Research, vol. 49, no. 1: pp. 66, 2018.

[23] Bowman, J.P., "Bioactive compound synthetic capacity and ecological significance of marine bacterial genus Pseudoalteromonas," Marine Drugs, vol. 5, no. 4: pp. 220-241, 2007.

[24] Ivanova, E.P., Chun, J., Romanenko, L.A., Matte, M.E., Mikhailov, V.V., Frolova, G.M., Huq, A., and Colwell, R.R., "Reclassification of Alteromonas distincta Romanenko et al. 1995 as Pseudoalteromonas distincta comb. nov," International Journal of Systematic and Evolutionary Microbiology, vol. 50, no. 1: pp. 141-144, 2000.

[25] Holmström, C., Egan, S., Franks, A., McCloy, S., and Kjelleberg, S., "Antifouling activities expressed by marine surface associated Pseudoalteromonas species," FEMS Microbiology Ecology, vol. 41, no. 1: pp. 47-58, 2002. 